\title{
Ion Pump Interaction
}

National Cancer Institute

\section{Source}

National Cancer Institute. Ion Pump Interaction. NCI Thesaurus. Code C40514.

Ion Exchanger Interaction consists of temporary non-covalent binding of a molecule through intermolecular physical forces of attraction with a membrane associated enzyme, or complex, involved in ATP-dependent transmembrane transport of a positively (cation) or negatively (anion) charg ed atom or radical ag ainst a concentration gradient resulting directly from the expenditure of energy. 